\title{
Evaluation of Sowing Methods of Upland and Ratooned Rice Planted in-between Lowland Rice-Fluted Pumpkin Sequence in Derived Savannah
}

\author{
Adigbo, S. O. ${ }^{1}$, Vaughan, I. O. ${ }^{2}$, Odedina, J. N. ${ }^{3}$, Adigbo, V. B. ${ }^{4}$, Ajayi, O. ${ }^{5}$ \& Nwilene, F. E. ${ }^{5}$ \\ ${ }^{1}$ Crop Research Programme, Institute of Food Security, Environmental Resource and Agricultural Research, \\ University of Agriculture, Abeokuta, Nigeria \\ ${ }^{2}$ Food Security and Scio-economics Research Programme, Institute of Food Security, Environmental Resource \\ and Agricultural Research, University of Agriculture, Abeokuta, Nigeria \\ ${ }^{3}$ Plant Physiology and Crop Production Department, University of Agriculture, Abeokuta, Nigeria \\ ${ }^{4}$ Plant breeding and Seed technology Department, University of Agriculture, Abeokuta, Nigeria \\ ${ }^{5}$ Africa Rice Center (WARDA), Ibadan 200001, Nigeria \\ Correspondance: Adigbo, S. O., Crop Research Programme, Institute of Food Security, Environmental Resource \\ and Agricultural Research, University of Agriculture, Abeokuta, Nigeria. E-mail: sundayadigbo@yahoo.com, \\ adigboso@unaab.edu.ng
}

Received: August 2, 2012 Accepted: September 5, 2012 Online Published: October 12, 2012

doi:10.5539/jas.v4n11p226 URL: http://dx.doi.org/10.5539/jas.v4n11p226

\begin{abstract}
The technical possibility of triple cropping in inland valleys is not in doubt but economic and agronomic performance of ratooned and upland rice (Oryza sativa L.) fitted in-between lowland rice and dry season cropping need to be ascertained. A field experiment was conducted at the Federal University of Agriculture, Abeokuta, Nigeria in 2007/2008 and 2008/2009 cropping season to compare the performance of sowing methods Dry dibble broadcast, pre-germinated broadcast, dry dibble, transplanted and pre-germinated broadcast methods of early maturing New Rice for Africa 1 (NERICA 1) upland rice were compared with ratooned crop of New Rice for Africa Lowland rice (NERICA-L) genotypes (NERICA-L 20, NERICA-L 26, NERICA-L 44, NERICA-L 41 and OFADA) in the niche between lowland rice and dry season cropping. The first crop was planted in May while the second and third were in September and December. The experiment was laid out in Randomized Complete Block Design (RCBD) with three replicates. The mean plant height, grains panicle ${ }^{-1}$, panicles $\mathrm{m}^{-2}, 1000$-grain weight and grain yield of lowland rice varieties were $126.5 \mathrm{~cm}, 220,173,29.3 \mathrm{~g}$, and $7.75 \mathrm{t} \mathrm{ha}^{-1}$, respectively. The ratooned lowland rice flowered earlier (28-37 days) than the upland rice sowing methods (66-77 days). Ratooned crops of NERICA-L 20, NERICA-L 26 and NERICA-L 44 had highest number of panicles $\mathrm{m}^{-2}$ and grain yield while pre-germinated dibble upland rice and ratooned crop of OFADA had the least panicles $\mathrm{m}^{-2}$ and grain yield, respectively. Transplanted upland rice and pre-germinated broadcast methods had better grain yield than any of the sowing methods of upland rice. The fresh leaf weight of fluted pumpkin (Telfairia occidentalis Hook F.) ranged between 14.59 and $19.77 \mathrm{t} \mathrm{ha}^{-1}$. Ratooned crops had better agronomic and economic performance than the upland rice. Hence the productivity of triple cropping in the inland valley could be efficiently utilized by adopting ratooning lowland rice.
\end{abstract}

Keywords: upland rice, ratooned rice, sowing methods, inland valley

\section{Introduction}

Nigeria is the second largest importer of rice in the World after the Philippines (Africa Rice Center, 2008). Nigeria imports one million tonnes of rice, valued at US\$700 m or about $\$ 106$ billion, from the Peoples Republic of Thailand every year (Sams, 2010) whereas Nigeria has the resource (abundant rainfed upland and inland valley) and management potential to produce enough rice to meet local needs and as well as for export (USDA 2001). Tropical Asia, with about $1 / 13$ of the world's land area, has more than $1 / 3$ of the potentially arable lowlands (FFTC, 2007). This explains the dominant role of Tropical Asia in rice production because the potential arable lowlands are efficiently utilized. 
Self sufficiency in rice in Nigeria, West Africa and indeed in Sub-Sahara Africa could be attained, if efforts are geared towards increasing crop intensification in the abundant inland valley where cultivation of arable crops can be done three times in a year (Adigbo et al., 2007; Adigbo et al., 2012; Adigbo et al., 2010) rather than dissipating energy in over-exploited upland ecology. Wetlands in sub-Saharan Africa are estimated to cover 228 million ha (Bergkamp et al., 2000). In West Africa, about 22-53 million ha of inland valley was estimated (Windmeijer \& Andriesse, 1993) and Nigeria has estimated 3 million ha (World Bank, 2006). Land intensification via triple cropping in inland valley, without irrigation, could be a viable option for resource-poor farmers, who accounted for $65 \%$ rice production.

Adigbo et al. (2007) explored the possibility of growing three crops without irrigation in the inland valley. Poor crop establishment was the major challenge associated with the second rice in the niche between lowland rice and dry season crops but this was resolved. The two likely available technologies that could optimize the existing niche between lowland rice and dry season crops are: 1) appropriate sowing methods of early maturing upland rice (Adigbo et al., 2010) and 2) ratooning of lowland rice (Adigbo et al., 2012). Rice ratooning is the practice of harvesting grain from tillers originating from the stubble of previously harvested crop (main crop) and it enhances rice grain yield without increasing land area because it provides higher resources use efficiency per unit land area per unit of time (Jason et al., 2005). There is the need to determine which of the two options is agronomically more productive vis a vis more economic to ensure social acceptability. The objective of this study is, therefore, to 1) compare the agronomic and economic performance of ratooned rice and upland rice fitted in the niche in-between lowland rice and dry season cropping and 2) compare the overall grain yield from each crops combination.

\section{Materials and Methods}

The experiment was conducted in 2007/2008 and 2008/2009 cropping seasons at the bottom of the inland valley of the University of Agriculture, Alabata, Abeokuta $\left(7^{\circ} 20^{\prime} \mathrm{N}, 3^{\circ} 23^{\prime} \mathrm{E}\right)$, Nigeria. The top 1 to $20 \mathrm{~cm}$ soil layer had $\mathrm{pH}\left(1: 2\right.$, soil/water) of $6.6,12.8 \mathrm{mg} \mathrm{kg}^{-1} \mathrm{~K}$ measured using Flame photometry, $1.32 \mathrm{~g} \mathrm{~kg}^{-1}$ total N (Macro-Kjedahl method) and $5.05 \mathrm{mg} \mathrm{kg}^{-1}$ Bray extractable P. The textural class of the soil was loamy soil (784 $\mathrm{g} \mathrm{kg}^{-1}$ sand, $164 \mathrm{~g} \mathrm{~kg}^{-1}$ silt, and $52 \mathrm{~g} \mathrm{~kg}^{-1}$ clay). The soil series of the experimental site was Ikire (Aiboni, 2001). This is equivalent of Aquic Ustifluvents according to Aiboni (2001).

The experiment was laid out in Randomize Complete Block Design (RCBD) in three replicates. Five improved ratoonable lowland rice varieties of 'New Rice for Africa' (NERICA) namely: NERICA-L 20, NERICA-L 24, NERICA-L 26, NERICA-L 44 and NERICA-L 41 collected from Africa rice Centre were planted along with $O F A D A$ (control). The $O F A D A$ and improved varieties were dry-seeded in May at the spacing $20 \times 20 \mathrm{~cm}$ on $3 \mathrm{~m}$ x $2 \mathrm{~m}$ in manually constructed beds when the rains became steady but before flooding. OFADA, NERICA-20, NERICA-L 24, NERICA-L 26, NERICA-L 44 varieties were planted to a plot each per replicate while NERICA-L 41 was planted in 5 plots of $3 \mathrm{~m}$ x $2 \mathrm{~m}$ per replicate and harvested in September. After harvesting, the standing rice straws OFADA, NERICA-20, NERICA-L 24, NERICA-L 26, NERICA-L 44 varieties were cut to about 5 to $10 \mathrm{~cm}$ above soil surface to stimulate ratoon growth whereas the straw of NERICA-L41 in the five plots per replicate were uprooted and each of the five beds reconstructed to accommodate the five methods of sowing upland rice in the niche between lowland rice and dry season crops. The preceding NERICA-L 41 variety was planted to five plots used for the succeeding upland rice to create uniformity, to some extent, the level of nutrient uptake from the soil prior to upland rice and ratooned rice. It also provides a level plain ground for comparison between ratooned rice and upland rice in terms of crop intensification.

The seeds of the upland rice were dry dibbled at spacing of $20 \mathrm{~cm} \times 20 \mathrm{~cm}$ and dry broadcasted on $23^{\text {rd }}$ and $7^{\text {th }}$ September, 2007 and 2008, respectively while the remaining seeds were pre-germinated for three days (between 23 and 25 September, 2007 and between $10^{\text {th }}$ and $12^{\text {th }}$ September, 2008). The pre-germinated seeds were broadcasted and dibbled on $25^{\text {th }}$ and $12^{\text {th }}$ of September, 2007 and 2008, respectively. The leftover of the pre-germinated seeds were nursed and transplanted at a spacing of $20 \mathrm{~cm}$ x $20 \mathrm{~cm}$ (two seedlings per hole) on $18^{\text {th }}$ October, 2007 and $5^{\text {th }}$ October, 2008.

The ratooned rice and upland rice straws were sprayed with herbicides after harvesting and the standing dead rice straw served as mulching to conserve the residual moisture and reduce weeds during dry season. Fruited pumpkin (Telfairia occidentalis), a popular vegetable was planted in all the plots in December 2007 and 2008 and harvested between February and April 2008 and 2009. The spacing was $50 \mathrm{~cm}$ x $50 \mathrm{~cm}$. The first harvest of the tender part of vine was done 4 Weeks After Emergence (WAE) to avoid apical dominance and stimulate branching. The subsequent harvesting was done fortnightly by cutting the tender part of the vines leaving behind about $30 \mathrm{~cm}$ from the node to ensure survival of the plant by using table knife. 
NPK 20:10:10 fertilizer at the rate of 30:15:15 kg NPK ha ${ }^{-1}$ was applied at 3 WAP while the second dose of fertilizer (30 kg N ha ${ }^{-1}$ in the form of urea) was applied at 9 and 11 WAP for upland rice and lowland rice respectively. But $60 \mathrm{~kg} \mathrm{~N}$ in form of Urea, $15 \mathrm{~kg} \mathrm{P} \mathrm{ha}^{-1}$ in form of single superphosphate and $15 \mathrm{~kg} \mathrm{~K} \mathrm{ha}^{-1}$ in form of muriate of potash for ratooned rice at $1 \mathrm{WAP}$.

\subsection{Data Collection}

\subsubsection{Agronomics data}

The following data were collected: number of days to $50 \%$ heading, plant height, panicles $\mathrm{m}^{-2}$, grains panicle ${ }^{-1}$, wt of 1000 seeds and grain yield.

\subsubsection{Financial Analysis}

Labour rates manday ${ }^{-1}$ and the price $\mathrm{kg}^{-1}$ of milled imported and OFADA rice were obtained from Ogun State Agricultural Development Programme (OGADEP). Paddy rice was converted to milled rice by multiplying the yield ha ${ }^{-1}$ and 0.76 . The price $\mathrm{kg}^{-1}$ of rice seeds was collected from Africa Rice Center.

All data collected from two crops were subjected to analysis of variance. The means of variables that recorded significant effects were further separated using Duncan Multiple Range Test (DMRT). Partial budget was done to determine the gross margin of each sowing methods.

\section{Results and Discussion}

Agronomic performance of the selected ratoonable lowland rice varieties are presented in Table 1. NERICA-L 26 consistently had the highest number of days to 50 percent heading in both cropping seasons whereas NERICA-L 20 and 24 had the lowest number of days to 50 percent heading in 2007/2008 and 2008/2009, respectively. The tallest plant was observed in OFADA variety while NERICA-L 44 had the shortest plant in both cropping seasons. The other varieties had similar plant height in both cropping seasons. The height of OFADA makes it vulnerable to lodging compared to other varieties. OFADA and NERICA-L 20 had the lowest no of grains panicle ${ }^{-1}$ while NERICA-L 26 had the highest in 2007/2008 cropping season but there was no significant difference in 2008/2009. NERICA-L 20 varieties had the highest 1000-grain weight while NERICA-L 26 had the lowest seed weight in 2008/2009 cropping season. NERICA-L 24 had the highest grain yield whereas OFADA was the lowest.

The performances of ratooned rice and upland rice in the niche of the two cropping seasons are presented in Table 2. The numbers of days to 50 percent heading among the ratooned rice varieties (27-37 days) were generally lower than those of early maturing upland rice (64-77 days). This confirms the report of Oad et al. (2002), who noted that ratooned crop has shorter growth duration. Ratooned rice plants of OFADA variety consistently flowered earlier than the others ratooned rice in both seasons. Upland rice had 1.83 to 2.85 times number of days to flower compared to ratooned rice varieties whereas main crop of lowland rice had 2.14 to 3.33 times number of days to flower compared to their ratooned counterparts. This obvious higher number of days to flowering of the previous lowland rice and upland rice in the niche was understandable, because the seed had to past through the lag, log and steady phases of seed to seedling development compared the ratooned counterpart which produces tiller from the already established root stock of the main crop. The transplanted upland rice had further delayed compared to the other sowing methods of upland rice. This could be attributed to slow recovery from transplanting shock. Adigbo et al. (2010) reported similar delay in transplanted upland rice.

Table 1. Agrononmic performance of selected ratoonable lowland rice varieties in 2007/2008 and 2008/2009 cropping seasons

\begin{tabular}{ccccccccccc}
\hline Lowland rice & \multicolumn{2}{c}{ Days to 50\% Heading } & \multicolumn{2}{l}{ Plant height $(\mathrm{cm})$} & \multicolumn{2}{c}{ No. of grains panicle ${ }^{-1}$} & \multicolumn{1}{c}{1000 -seed wt. (gm) } & Grain yield t ha $^{-1}$ \\
\hline & $2007 /$ & $2008 /$ & $2007 /$ & $2008 /$ & $2007 /$ & $2008 /$ & $2007 /$ & $2008 /$ & $2007 /$ & $2008 /$ \\
& 2008 & 2009 & 2008 & 2009 & 2008 & 2009 & 2008 & 2009 & 2008 & 2009 \\
\hline NERICA-L 20 & $90 \mathrm{c}$ & $94 \mathrm{~b}$ & $126.6 \mathrm{bc}$ & $129.9 \mathrm{bc}$ & $162 \mathrm{c}$ & $159 \mathrm{a}$ & $27.05 \mathrm{a}$ & $31.56 \mathrm{a}$ & $5.97 \mathrm{a}$ & $6.46 \mathrm{~b}$ \\
NERICA-L 24 & $93 \mathrm{~b}$ & $91 \mathrm{c}$ & $123.0 \mathrm{bc}$ & $134.9 \mathrm{bc}$ & $236 \mathrm{ab}$ & $163 \mathrm{a}$ & $27.80 \mathrm{a}$ & $29.08 \mathrm{~cd}$ & $6.25 \mathrm{a}$ & $9.41 \mathrm{a}$ \\
OFADA & $84 \mathrm{~d}$ & $85 \mathrm{~d}$ & $187.1 \mathrm{a}$ & $186.4 \mathrm{a}$ & $168 \mathrm{c}$ & $163 \mathrm{a}$ & $24.06 \mathrm{a}$ & $27.48 \mathrm{~cd}$ & $3.59 \mathrm{~b}$ & $4.13 \mathrm{c}$ \\
NERICA-L 26 & $97 \mathrm{a}$ & $99 \mathrm{a}$ & $135.0 \mathrm{~b}$ & $134.8 \mathrm{bc}$ & $249 \mathrm{a}$ & $180 \mathrm{a}$ & $25.76 \mathrm{a}$ & $26.87 \mathrm{~d}$ & $6.42 \mathrm{a}$ & $5.70 \mathrm{bc}$ \\
NERICA-L 41 & $91 \mathrm{bc}$ & $93 \mathrm{bc}$ & $130.3 \mathrm{~b}$ & $141.1 \mathrm{~b}$ & $232 \mathrm{ab}$ & $186 \mathrm{a}$ & $27.92 \mathrm{a}$ & $29.51 \mathrm{abc}$ & $7.31 \mathrm{a}$ & $7.48 \mathrm{ab}$ \\
NERICA-L 44 & $93 \mathrm{~b}$ & $95 \mathrm{~b}$ & $117.7 \mathrm{c}$ & $121.4 \mathrm{c}$ & $194 \mathrm{bc}$ & $166 \mathrm{a}$ & $25.49 \mathrm{a}$ & $29.87 \mathrm{ab}$ & $6.29 \mathrm{a}$ & $7.91 \mathrm{ab}$ \\
*F-Test (V) & $<0.001$ & $<0.001$ & $<0.001$ & $<0.001$ & $<0.01$ & NS & NS & $<0.01$ & $>0.05$ & $<0.002$ \\
\hline
\end{tabular}

NS= Not significant. 
Table 2. Agronomic performance of ratooned lowland rice/upland rice varieties in 2007/2008 and 2008/2009 cropping seasons

\begin{tabular}{|c|c|c|c|c|c|c|c|c|c|c|c|c|}
\hline \multirow{3}{*}{$\begin{array}{l}\text { Treatments } \\
\text { Sowing methods (SM) }\end{array}$} & \multicolumn{2}{|c|}{ Days to $50 \%$ Heading } & \multicolumn{2}{|c|}{ Plant height (cm } & \multicolumn{2}{|c|}{ Panicles $\mathrm{m}^{-2}$} & \multicolumn{2}{|c|}{ No. of grains panicle ${ }^{-1}$} & \multicolumn{2}{|c|}{ 1000-seed wt. (gm } & \multicolumn{2}{|c|}{ Grain yield $t \mathrm{ha}^{-1}$} \\
\hline & \multirow{2}{*}{$2007 / 2008$} & \multirow{2}{*}{$2008 / 2009$} & $2007 /$ & 2008/ & $2007 /$ & 2008/ & \multirow{2}{*}{$2007 / 2008$} & \multirow{2}{*}{$2008 / 2009$} & \multirow{2}{*}{$\begin{array}{l}2007 / \\
2008\end{array}$} & \multirow{2}{*}{$\begin{array}{l}2008 / \\
2009\end{array}$} & \multirow{2}{*}{$\begin{array}{l}2007 / \\
2008\end{array}$} & \multirow{2}{*}{$\begin{array}{l}2008 / \\
2009\end{array}$} \\
\hline & & & 2008 & 2009 & 2008 & 2009 & & & & & & \\
\hline NERICA-L 20 & $34 \mathrm{~cd}$ & $40 \mathrm{c}$ & $86.5 \mathrm{~cd}$ & $108.6 \mathrm{bc}$ & $300 \mathrm{a}$ & $187 \mathrm{ab}$ & $95 \mathrm{~cd}$ & $131 \mathrm{~b}$ & $28.50 \mathrm{bcd}$ & $31.78 \mathrm{a}$ & $4.08 \mathrm{a}$ & $3.42 \mathrm{a}$ \\
\hline NERICA-L 24 & $32 \mathrm{~d}$ & $42 \mathrm{c}$ & $98.6 \mathrm{~b}$ & $113.3 \mathrm{~b}$ & $131 b c$ & $141 \mathrm{bc}$ & $109 \mathrm{c}$ & $126 \mathrm{~b}$ & $27.12 \mathrm{~cd}$ & $26.68 \mathrm{bc}$ & $2.24 \mathrm{~b}$ & $3.20 \mathrm{ab}$ \\
\hline OFADA & $27 \mathrm{e}$ & $29 \mathrm{e}$ & $117.1 \mathrm{a}$ & $127.1 \mathrm{a}$ & $104 \mathrm{bcd}$ & $103 \mathrm{c}$ & $86 \mathrm{~cd}$ & $139 b$ & $25.50 \mathrm{~d}$ & $31.04 \mathrm{a}$ & $1.07 \mathrm{~cd}$ & $1.20 \mathrm{~d}$ \\
\hline NERICA-L 26 & $37 \mathrm{c}$ & $33 \mathrm{de}$ & $98.7 b$ & $104.3 \mathrm{~cd}$ & $278 \mathrm{a}$ & 221a & $69 \mathrm{~d}$ & $97 \mathrm{~d}$ & $25.73 \mathrm{~d}$ & $25.67 \mathrm{c}$ & $4.66 \mathrm{a}$ & $2.61 \mathrm{abc}$ \\
\hline NERICA-L 44 & $33 \mathrm{~d}$ & $37 \mathrm{~cd}$ & $79.1 \mathrm{~d}$ & $93.5 \mathrm{ef}$ & $254 \mathrm{a}$ & $214 \mathrm{a}$ & $89 \mathrm{~cd}$ & $101 \mathrm{~cd}$ & $27.74 \mathrm{bcd}$ & $26.58 \mathrm{bc}$ & $4.09 \mathrm{a}$ & $2.98 \mathrm{abc}$ \\
\hline Dry broadcast & $67 \mathrm{~b}$ & $65 \mathrm{~b}$ & $98.2 \mathrm{bc}$ & $87.9 \mathrm{f}$ & $47 \mathrm{de}$ & $214 a$ & $165 \mathrm{ab}$ & $91 \mathrm{~d}$ & $32.09 \mathrm{a}$ & $29.90 \mathrm{ab}$ & $0.75 \mathrm{~d}$ & $2.01 \mathrm{abc}$ \\
\hline Dry dibble & $66 \mathrm{~b}$ & $64 \mathrm{~b}$ & $96.5 \mathrm{bc}$ & $99.7 \mathrm{de}$ & $34 \mathrm{e}$ & $145 \mathrm{bc}$ & $182 \mathrm{ab}$ & $136 \mathrm{~b}$ & $29.89 \mathrm{abc}$ & $29.56 \mathrm{abc}$ & $0.59 \mathrm{~d}$ & $2.32 \mathrm{abcc}$ \\
\hline Pre-germinated dibble & $66 \mathrm{~b}$ & $69 b$ & $100.6 \mathrm{~b}$ & $104.3 \mathrm{~cd}$ & $80 \mathrm{~cd}$ & $133 \mathrm{bc}$ & $168 \mathrm{ab}$ & $144 \mathrm{~b}$ & $28.44 \mathrm{bcd}$ & $28.02 \mathrm{abc}$ & $1.56 \mathrm{bcd}$ & $2.29 \mathrm{bcd}$ \\
\hline Pre-germinated broadcast & $66 \mathrm{~b}$ & $66 \mathrm{~b}$ & $97.5 \mathrm{bc}$ & $94.7 \mathrm{e}$ & $133 b$ & 164abc & $149 \mathrm{~b}$ & $121 \mathrm{bc}$ & $30.05 \mathrm{abc}$ & $29.41 \mathrm{abc}$ & $1.81 \mathrm{bc}$ & $2.20 \mathrm{bcd}$ \\
\hline Transplanted & $77 \mathrm{a}$ & $77 \mathrm{a}$ & $107.5 \mathrm{ab}$ & $107.5 \mathrm{bc}$ & $142 \mathrm{bc}$ & $126 \mathrm{bc}$ & $186 \mathrm{a}$ & $175 \mathrm{a}$ & $30.48 \mathrm{ab}$ & $26.50 \mathrm{bc}$ & $2.28 \mathrm{~b}$ & $1.93 \mathrm{~cd}$ \\
\hline *F-Test & $<0.01$ & $<0.01$ & $<0.010$ & $<0.010$ & $<0.01$ & $<0.010$ & $<0.01$ & $<0.01$ & $<0.01$ & $<0.05$ & $<0.001$ & $<0.020$ \\
\hline
\end{tabular}

*Significance ( $\mathrm{p}$ value)

The plant heights of ratooned and upland rice were generally comparable. But ratooned rice of OFADA variety had the tallest plant in both seasons while ratooned rice of NERICA-L 44 variety and dry broadcasted upland rice had the shortest plants in 2007/2008 and 2008/2009, respectively. The number of panicles $\mathrm{m}^{-2}$ observed in ratooned rice appeared to be higher than the upland rice in both seasons although the number of panicles was more comparable in 2008/2009 than 2007/2008. The lower number of panicles $\mathrm{m}^{-2}$ observed in the upland rice in 2007/2008 cropping season could be attributed to rainfall amount and distribution at the time of planting (Figure 1). There was a dry spell few days to seeding, during and 17 days after seeding in 2008/2009 cropping season thus, creating a temporarily moisture condition that is similar to the upland ecology. However, the soil was saturated before, during and after the seeding of upland rice in 2007/2008 cropping seasons which affected crop emergence. Such unprecedented rainfall distribution necessitated the process of pre-germinating upland rice, nursing seedlings and transplanting which had demonstrated its worthwhile effort to enhance crop establishment.

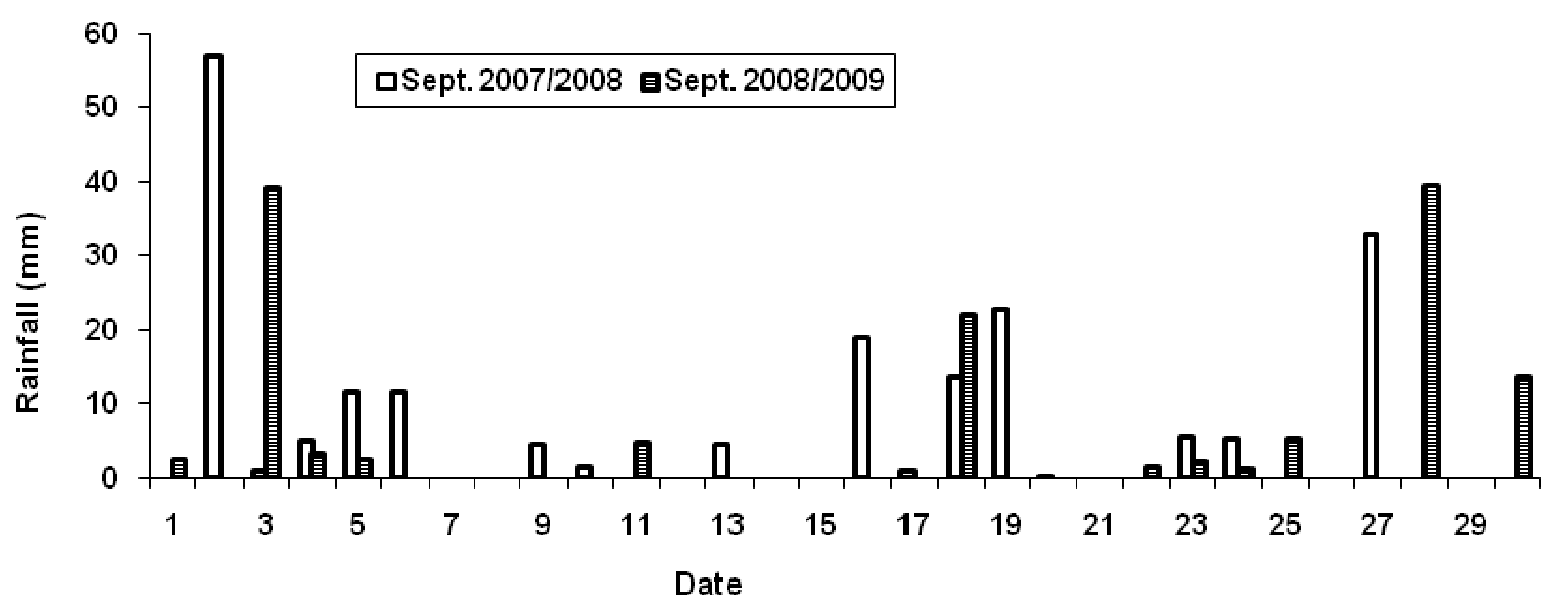

Figure 1. Daily rainfall data during the planting period of the of upland rice in the niche in 2007/2008 and 2008/2009 cropping seasons

The number of grains panicle ${ }^{-1}$ observed in upland rice was significantly higher than those of ratooned rice in $2007 / 2008$ compared to that of 2008/2009 which was fairly comparable. This differential observation could be attributed to poor crop establishment arising from rainfall distribution and the resultant low population density associated with the lack of inter- and intra-row competition for growth resources among the rice plants within the plot. However, transplanting had the highest grains panicle ${ }^{-1}$ while ratooned rice variety of NERICA-L 26 had 
lowest in both cropping seasons. The dry broadcast had the heaviest seed in 2007/2008 whereas ratooned rice varieties of OFADA and NERICA-L 20 had the heaviest seed in 2008/2009. However, NERICA-L 26 consistently had the lightest seed in both seasons. These variations were not unconnected to the inherent genotype of the ratooned and the treatments imposed on the upland rice.

Generally, the ratooned lowland rice had higher grain yield than the upland in the two cropping seasons. The yields of ratooned lowland rice were higher in 2007/2008 than 2008/2009 cropping season whereas the reverse was the case for upland rice. The ratooned lowland NERICA-L 20, 26 and 44 were consistently among the highest grain yielder in both cropping seasons while OFADA had the lowest grain yield among the ratooned rice. The transplanting method which is not common practice among the farmers had significantly higher grain yields than dry dibble and dry broadcast methods but had comparable grain yields with those of pre-germinated dibble and pre-germinated broadcast methods in 2007/2008 cropping season. The extreme low grain yield obtained from dry dibbling of upland rice could be attributed to poor respiration in anaerobic condition of the soil in the niche between lowland rice and dry season cropping. This poor germination was also reported by Adigbo et al. (2007). This suggests that transplanted seedlings, pre-germinated dibble and pre-germinated help to overcome poor emergence and thus, improving the performance of upland rice in niche.

The grain yield of transplanted seedlings and those of ratooned rice in the inland valley in 2007/2008 cropping season was substantially higher than the obtainable yield of $1.5 \mathrm{t} \mathrm{ha}^{-1}$ (IITA 1990), $1.19 \mathrm{t} \mathrm{ha}^{-1}$ (Adigbo et al. 2003) and $1.38 \mathrm{t} \mathrm{ha}^{-1}$ (Africa Rice Center, 2008) in upland ecology. Consequently, to maximize the existing niche for high grain yield desirability, ratooning of lowland rice, transplanting method, pre-germinated dibbled and pre-germinated broadcast methods of NERICA upland rice could be viable technologies to improving grain yield in the inland valley particularly for the years with poor rainfall distribution.

The fresh leaf yields of the fluted pumpkin obtained in both cropping seasons were similar (Table 3). However, fresh leaf yield in 2008/2009 was higher than those of 2007/2008 perhaps due to higher rainfall in early 2009 . Adekanbi et al. (2007) who investigated the effect of compost and inorganic fertilizer in fluted pumpkin during the rainy season reported shoot yield of $19.7 \mathrm{t} \mathrm{ha}^{-1}$ in plots without fertilizer whereas Phillips et al. (2009) reported $7.82 \mathrm{t} \mathrm{ha}^{-1}$ and $5.93 \mathrm{t} \mathrm{ha}^{-1}$ in 2006 and 2007, respectively during the rainy season. These results suggested that the triple cropping did not suppress fresh leaf weight of fluted pumpkin in the inland valley.

Table 3. Fresh leaf weight of fruited pumpkin $\left(\mathrm{t} \mathrm{ha}^{-1}\right)$

\begin{tabular}{lll}
\hline Treatments & $2007 / 2008$ & $2008 / 2009$ \\
\hline NERICA-L 20 & $15.25 \mathrm{a}$ & $19.77 \mathrm{a}$ \\
NERICA-L 24 & $14.59 \mathrm{a}$ & $19.29 \mathrm{a}$ \\
OFADA & $16.71 \mathrm{a}$ & $18.67 \mathrm{a}$ \\
NERICA-L 26 & $16.90 \mathrm{a}$ & $18.67 \mathrm{a}$ \\
NERICA-L 44 & $16.11 \mathrm{a}$ & $19.39 \mathrm{a}$ \\
Dry broadcast & $15.68 \mathrm{a}$ & $19.32 \mathrm{a}$ \\
Dry dibble & $15.13 \mathrm{a}$ & $18.68 \mathrm{a}$ \\
Pre-germinated dibble & $16.28 \mathrm{a}$ & $18.45 \mathrm{a}$ \\
Pre-germinated broadcast & $15.51 \mathrm{a}$ & $18.32 \mathrm{a}$ \\
Transplanted & $15.31 \mathrm{a}$ & $19.68 \mathrm{a}$ \\
F-Test Significance (p value) & $>0.05$ & $>0.05$ \\
\hline
\end{tabular}

The average total grain yield obtained from the two crops of rice in eight months ranged between 5.67 and 10.94 $\mathrm{t} \mathrm{ha}^{-1}$ compared to single crop of lowland rice (which ranged between 4.53 and $7.83 \mathrm{t} \mathrm{ha}^{-1}$ ) currently being practiced (Table 4). The ratooned crop NERICA-L 20, NERICA-L 24, OFADA, NERICA-L 26 and NERICA-L 44 contributed about $37.6,25.8,20.137 .5$ and $47.8 \%$ to the total grain yield, respectively. The sowing methods of upland rice, transplanting, pre-germinated dibble and pre-germinated broadcast contributed about 22.2, 20.7, and $21.4 \%$, respectively to the overall grain yield of the rice crops per year while dry dibble and dry broadcast contributed 16.5 and $15.7 \%$, respectively. This is a clear indication that ratooned lowland rice is more productive than upland rice. 
Table 4. Average total grain yield and percentage yield contribution of ratooned rice and upland rice of the two cropping seasons

\begin{tabular}{ccccc}
\hline Sowing methods (SM) & $\begin{array}{c}\text { Main grain } \\
\text { yield (t ha)rice grain yield (t ha) } 8\end{array}$ & $\begin{array}{c}\text { Total grain yield in } \\
\text { months (t ha-yr-1) contributions (\%) }\end{array}$ \\
\hline NERICA-L 20 & 6.22 & 3.75 & 9.97 & $37.6(60.3)$ \\
NERICA-L 24 & 7.83 & 2.72 & 10.55 & $25.8(34.7)$ \\
OFADA & 4.53 & 1.14 & 5.67 & $20.1(25.2)$ \\
NERICA-L 26 & 6.06 & 3.63 & 9.69 & $37.5(59.9)$ \\
NERICA-L 44 & 7.10 & 3.54 & 10.64 & $47.8(49.9)$ \\
NERICA-L 41 & 7.40 & - & 7.40 & - \\
Dry broadcast & 7.40 & 1.38 & 8.78 & 15.7 \\
Pre-germinated Dibble & 7.40 & 1.93 & 9.33 & 20.7 \\
Dry Dibble & 7.40 & 1.46 & 8.86 & 16.5 \\
Transplanted & 7.40 & 2.11 & 9.52 & 22.2 \\
Pre-germinated broadcast & 7.40 & 2.01 & 9.41 & 21.4 \\
\hline
\end{tabular}

Obtainable yield in upland ecology and $1.38 \mathrm{t} \mathrm{ha}^{-1}$ (Africa Rice Center, 2008).

The value in parenthesis which is a measure of the ratoonability of the lowland rice varieties indicated that OFADA had the least ability to ratoon while NERICA-L 20 and 26 had the highest ability to ratoon. The lowland rice varieties NERICA-L 20 and 26 had more than 50 of the main yield. These values are higher than the finding of Rehman et al. (2007) who report that the yield of ratooned rice was up to 50 per cent of the main crop. The ratoonability of NERICA-L 44 and 24 were within the range reported by Stansel (1997) and Oad et al. (2002) who documented that the ratooned rice yield was between 30 and $50 \%$ of the main crop.

The partial budget was used to evaluate the gross margin derivable from the various sowing methods and ratoonable lowland varieties in the niche between lowland rice and dry season farming (Table 5). OFADA which is common varieties among the farmers in South Western Nigeria has high premium market because of the unique taste and flavor. The ratooned rice from OFADA variety had lowest gross benefit whereas NERICA-L 20 had the highest. NERICA-L 20 had 1.68, 1.38, 1.33 and 1.04 times higher gross benefit than those of NERICA-L 44, NERICA-L 24, OFADA and NERICA-L 26, respectively of the lowland rice. However, in upland rice sowing methods, transplanting had 1.52, 1.44, 1.09 and 1.05 times gross benefit than those of dry broadcast, dry dibbled, pre-germinated dibbled and pre-germinated broadcast.

The higher grain yield in the ratooned lowland rice resulted in higher gross benefit than the upland rice counterpart. The total variable costs obtained from ratooned lowland rice varieties were substantially lower than those of upland rice sowing methods because the cost of uprooting the rice straws, seedbed preparation, seed materials and seeding were zero in ratooned rice. However, transplanting which had highest gross benefit also had the highest variable cost thereby leading to reduction in the gross margin. It is pertinent to note that transplanted seedlings and pre-germinated broadcasted seeds had highest gross margins in years with erratic rainfall. But since it is not within power of the farmer to predict the pattern of rainfall before the on-set the cropping season, the choice of sowing methods of upland rice in the niche becomes a vital decision. 
Table 5. Gross margin in naira per hectare obtained from different sowing methods of rice during the niche in inland valley

\begin{tabular}{|c|c|c|c|c|c|c|c|c|c|c|}
\hline \multirow[b]{2}{*}{$\begin{array}{c}\text { Gross } \\
\text { benefit }\end{array}$} & \multicolumn{5}{|c|}{ Ratooned lowland rice } & \multicolumn{5}{|c|}{ Sowing methods of upland rice } \\
\hline & $\begin{array}{l}\text { NERICA- } \\
\text { L } 20\end{array}$ & $\begin{array}{l}\text { NERICA- } \\
\text { L } 24\end{array}$ & OFADA & $\begin{array}{l}\text { NERICA- } \\
\text { L } 26\end{array}$ & $\begin{array}{l}\text { NERICA- } \\
\text { L } 44\end{array}$ & $* \mathrm{DB}$ & PD & DD & TP & PB \\
\hline $\begin{array}{l}\text { 1. Average } \\
\text { yield } \\
(\mathrm{kg} / \mathrm{ha})\end{array}$ & 3760.00 & 2720.00 & 1135.00 & 3630.00 & 3540.00 & 1380.00 & 1930.00 & 1460.00 & 2100.00 & 2000.00 \\
\hline $\begin{array}{l}\text { 2. Price } \\
\text { ( } \mathbb{N} / \mathrm{kg})\end{array}$ & 240.00 & 240.00 & 600.00 & 240.00 & 240.00 & 240.00 & 240.00 & 240.00 & 240.00 & 240.00 \\
\hline $\begin{array}{l}\text { 3. Gross } \\
\text { benefits } \\
\left(\begin{array}{c}\mathrm{N} a) \\
\text { 2) }(1 \mathrm{x}\end{array}\right.\end{array}$ & $\begin{array}{c}381,013.3 \\
3\end{array}$ & $\begin{array}{c}275,626.6 \\
7\end{array}$ & $\begin{array}{c}287,533.3 \\
3\end{array}$ & $\begin{array}{c}367,840.0 \\
0\end{array}$ & $\begin{array}{c}227,189.3 \\
3\end{array}$ & $\begin{array}{c}139,840.0 \\
0\end{array}$ & $\begin{array}{c}195,573.3 \\
3\end{array}$ & $\begin{array}{c}147,946.6 \\
7\end{array}$ & $\begin{array}{c}212,800.0 \\
0\end{array}$ & $\begin{array}{c}202,666.6 \\
7\end{array}$ \\
\hline \multicolumn{11}{|l|}{$\begin{array}{l}\text { Variable } \\
\text { inputs }\end{array}$} \\
\hline $\begin{array}{l}\text { 4. Slash, } \\
\text { bed \& } \\
\text { ratooning } \\
\text { /ha }\end{array}$ & $16,000.00$ & $16,000.00$ & $16,000.00$ & $16,000.00$ & $16,000.00$ & $30,000.00$ & $30,000.00$ & $30,000.00$ & $30,000.00$ & $30,000.00$ \\
\hline $\begin{array}{l}\text { 5. Labour } \\
\text { for seeding }\end{array}$ & 0.00 & 0.00 & 0.00 & 0.00 & 0.00 & $14,800.00$ & $26,000.00$ & $26,000.00$ & $\begin{array}{c}90 \\
000.00\end{array}$ & $14,800.00$ \\
\hline $\begin{array}{l}\text { 6. Seed } \\
\text { procureme } \\
\text { nt }\end{array}$ & 0.00 & 0.00 & 0.00 & 0.00 & 0.00 & $16,000.00$ & $12,000.00$ & $12,000.00$ & $8,000.00$ & $16,000.00$ \\
\hline $\begin{array}{c}\text { 7. Total } \\
\text { variable } \\
\text { cost } \\
\left(\sum 4 \ldots 6\right)\end{array}$ & $16,000.00$ & $16,000.00$ & $16,000.00$ & $16,000.00$ & $16,000.00$ & $60,800.00$ & $68,000.00$ & $68,000.00$ & $\begin{array}{c}128,500.0 \\
0\end{array}$ & $60,000.00$ \\
\hline $\begin{array}{l}\text { 8. Gross } \\
\text { margin } \\
(\mathbb{A} / \mathrm{ha}) \\
(3-7)\end{array}$ & $\begin{array}{c}365,013.3 \\
3\end{array}$ & $\begin{array}{c}259,626.6 \\
7\end{array}$ & $\begin{array}{c}271,533.3 \\
3\end{array}$ & $\begin{array}{c}351,840.0 \\
0\end{array}$ & $\begin{array}{c}211,189.3 \\
3\end{array}$ & $79,040.00$ & $\begin{array}{c}127,573.3 \\
3\end{array}$ & $79,946.67$ & $84,300.00$ & $\begin{array}{c}142,666.6 \\
7\end{array}$ \\
\hline
\end{tabular}

1. Man day $=\$ 800$, sowing rice seeds $=32.5$ man day ha ${ }^{-1}$, broadcasting $=18.5$ man day $/$ ha, clearing and bed making $=37.5$ man day $\mathrm{ha}^{-1}$, cutting rice straw 20 man day ha ${ }^{-1}, 75$ man day ha ${ }^{-1}$ for transplanting seedling @ $\$ 1200$ per man day;

2.1 kogo weigh $($ standard measurement $)=1.80 \mathrm{~kg}, 1$ kogo of OFADA $=\$ 600,1$ kogo of imported rice $=\$ 240$ Market prices for the new varieties were assumed to be equal to those imported milled rice;

$3.1 \mathrm{~kg}$ of rice seed $=\$ 200,0.76 \%$ of paddy rice $=$ milled rice, $\quad \$ 150$ (Nigeria naira) $=$ US $\$ 1$;

4. Seed rate for dibbling $=60 \mathrm{~kg} \mathrm{ha}^{-1}$, broadcasting $=80 \mathrm{~kg} \mathrm{ha}^{-1}$, transplanting $40 \mathrm{~kg} \mathrm{ha}^{-1}$;

5. $* \mathrm{DB}=$ dry broadcast, $\mathrm{PD}=$ pre-germinated dibble, $\mathrm{DD}=$ dry dibble, $\mathrm{TP}=$ transplanted and $\mathrm{PB}=$ pre-germinated broadcast.

The gross margin obtained from ratooned lowland rice ranged between $\$ 211,189.33$ (US\$1407.93) and $\$ 365013.33$ (US\$2433.4222) while those of upland sowing methods were between $\$ 79,040.00$ (US\$526.93) and $\$ 142,666.67$ (US\$951.11). The gross margin obtained from NERICA-L 20 had 1.73, 1.41, 1.34 and 1.04 times higher than NERICA-L 44, 24, OFADA and 26, respectively. When price discounts for improved varieties were assumed to be equal to the imported rice, OFADA ranked second in gross margins. But the market value of these new varieties is not known in terms of the willingness of the consumers' to pay more or less compared to the imported rice since they have not been released to farmers in Nigeria.

The pre-germinated broadcast method of sowing upland rice had 1.81, 1.78, 1.69 and 1.12 times higher than those of dry broadcast, dry dibbled seeds, transplanted seedlings and pre-germinated methods. The total variable cost incurred in the production of upland rice in the niche was generally higher than those of ratooned counterpart. Moreover, ratooned rice varieties were more productive than the upland rice. Therefore, it is more economical to include ratooned rice in the niche between lowland rice and vegetable than upland rice. The farmer may, however, choose to produce upland varieties in the niche if their qualities are superior and the market price justifies it. Adigbo and Adigbo (2010) gave a similar report on the farmers holding onto the lower yielding local varieties of cowpea with high market premium instead of adopting improved high yielding varieties with poor taste and cooking qualities. 


\section{Conclusion}

Based on this study, the two options are capable of improving the productivity of inland valley. However, ratooned crops had better agronomic and economic performance than the upland rice. Hence the productivity of triple cropping in the inland valley could be efficiently utilized by adopting ratooning lowland rice.

\section{References}

Adekanbi, W. B., Adebooye, C. O., Togun, A. O., Ogunrinde, J. O., \& Adeyeye, S. A. (2007). Growth, Herbage and Seed Yield and Quality of Telfairia occidentalis as Influenced by Cassava Peel Compost and Mineral Fertilizer. World Journal of Agricultural Sciences, 3(4), 508-516.

Adigbo, S. O., \& Adigbo, V. B. (2010). Effects of site and insecticide application on growth and grain yield of local and improved cowpea varieties in south-western Nigeria. Archives of Agronomy and Soil Science, 57(2), 179-191. http://dx.doi.org/10.1080/03650340903225032

Adigbo, S. O., Olojede, M. O., Harris, P. J. C., \& Ajayi, O. (2012). Ratooned lowland NERICA rice varieties as an option for triple cropping in inland valleys of derived savannah in Nigeria. Experimental Agriculture, 48 (4), 551-562.

Adigbo, S. O. (2008). Evaluation of Lowland Rice 'NERICA Varieties' and their Ratooning Ability in an Inland Valley.

Adigbo, S. O., Ojerinde, A. O., Ajayi, O., \& Nwilene, F. E. (2010). Effect of sowing methods on performance of upland rice in lowland rice-upland rice-vegetable sequence in inland valley. Journal of Agricultural science and technology, 4(3), 1-10.

Adigbo, S. O., Okeleye, K. A., \& Adigbo, V. B. (2007). Performance of upland rice fitted into lowland rice and vegetable/cowpea sequence in inland valley. Agronomy Journal, 99, 377-383. http://dx.doi.org/10.2134/agronj2005.0170

Adigbo, S. O, Okeleye, K. A., Ariyo, O. J., \& Olowe, V. I. O. (2003). Effects of mucuna residue (Mucuna utilis) incorporation and $\mathrm{N}$ fertilizer on the performance of upland rice. Nigerian Journal of Agriculture, 34, 49-59.

Africa Rice Center. (2008). Africa Rice Trends 2007. Cotonou, Benin: Africa Rice Center (WARDA).

Aiboni, V. U. (2001). Characteristics and classification of soils of a representative topographic location in the University of Agriculture Abeokukuta, 1(1), 35-50.

Bergkamp, G., Pirot, J. Y., \& Hostettler, S. (2000). Integrated wetlands and water resources management. IUCN, Gland, Switzerland.

Food \& Fertilizer Technology Center (FFTC). (2007). Ecological Sustainability of the paddy Soil-Rice System in Asia. Retrieved 2007 from: http://www.agnet.org/library

IITA. (1990). IITA Annual Report 1989/1990 (pp 82-43). Ibadan, Nigeria.

Jason, B., James, P. L., \& Ronald, P. R. (2005). Fertilization of ratoon rice in Louisiana State University. Journal of Crop Science, 53(2), 10-15.

Oad, F. C., Ponpe, S. C., Memon, N., Oad, N. L., \& Hazzan, Z. (2002). Rice Ratooning Management. Pakistan Journal of Applied Sciences, 2(1), 20-35.

Phillips, B., Shittu, A. M., Aiyelaagbe, I. O. O., \& Adedokun, T. (2009). Economic potentials of plantain and fluted pumpkin intercropping as a poverty reduction strategy in South-Western Nigeria World. Journal of Agricultural Sciences, 5(5), 525-534.

Rehman, H. U., Farooq, M., \& Basra, S. M. A. (2007). Rice ratooning: a technology to increase production. Retrieved from: http://dawn.com/fixed/contribution/contribution.htm

Sams, N. (2010). Nigeria spends N106b to import rice from Thailand. Retrieved from: $\mathrm{http} / / / 234$ next.com/csp/cms/sites/Next/Money/Business/5519234-147/story.csp

Stansel, J. (1997). Cost-cutting fertilization and ratooning technologies shown at Beaumont field day. Press release for the Texas A \& M, Agricultural Research and Extension Center, Beaumont Texas July 1997.

USDA. (2001). Nigeria Rice Production Increases and Import Duty Raised. Accessed on 2nd of January, 2009.

West Africa Rice Development Association (WARDA). (1993). Development of lands. In: Training in rice production (pp. 29-46). Instructor's manual. West Africa Rice Development Association. Hong Kong, 1993. 
Windmeijer, P. N., \& Andriesse, W. (1993). Inland valleys in West Africa. An agro-ecological characterization of rice growing environments. Land Reclamat. and Improvement, Publ. 52. Int. Inst: Wageningen, the Netherlands.

World Bank. (2006). Press Release-Nigeria Receives Aid To Manage At-Risk Water Ecosystems. http://usinfo.state.gov. Accessed on the 8th December, 2006. 